胃癌所属リンパ節の細胞性免疫能

\begin{tabular}{llll}
\multicolumn{5}{c}{ 九州大学生体防御医学研究所外科 } \\
木場 & 文男 & 秋吉 & 毅 有永 信哉 \\
和田 哲哉 & 过 秀男 & &
\end{tabular}

\title{
CELL-MEDIATED IMMUNITY IN REGIONAL LYMPH NODES FROM PATIENTS WITH GASTRIC CANCER
}

\section{Fumio KOBA, Tsuyoshi AKIYOSHI, Shinya ARINAGA, Tetsuya WADA and Hideo TSUJI}

Department of Surgery, Medical Institute of Bioregulation, Kyushu University

真引用語：胃癌, 所属リンパ節, 細胞性免疫能

はじめに

癌所属リンパ節が抗腫瘍免疫において，どのような 役割を担っているかについては，移植腫晹を用いた動 物実験により多くの検索がなされてきた，その結果， 腫癔免疫の成立に重要な役割をはたしていることが認 められてきている、しかし，癌患者の抗腫瘍免疫にお ける所属リンパ節の免疫学的意義については方法論的 な問題すあることから十分な検討がなされてきたとは いい難い.

最近，腫瘍に対する免疫監視機構において働くと考 えられるェファクターについて多くの検索がなされて きた，そして，抗腫瘍性に㗢く killer 活性を持った細 胞が認められている。そこで，私どすは癌手術に拉け るリンパ節郭清の意義について検索を試みるといら立 場から, 胃癌所属リンパ節について, 抗腫瘍性に働く と考兄られる killer 細胞活性を測定し，同一患者末梢 血および良性疾患と比較したので報告する。

\section{対刍およひ方法}

\section{I. 対象}

1982年 4 月より1984年 6 月までに当科にて手術を施 行した良性疾患（胃・十二指腸潰瘍および胆石症）患 者49例と，胃癌患者84例を対象とした。

II. 実験方法

\footnotetext{
※第26回日消外総会シンポ II：消化器癌リンパ節応答 とその郭清 $<1985$ 年11月 12 日受理 $>$ 別刷請求先：木場 文男 干874 別府市大字鶴見字鶴見原4546 九州大学生医 研外科
}

\section{1.リンパ球の分離}

末梢血リンパ球（peripheral blood lymphocytes 以 下 PBL) は, ヘパリン加採血した末梢静脈血より Ficoll-Conray 法により分離した。 また，胃癌患者の所 属リンパ節リンパ球（regional lymph node cells 以下 RLNC）は，リンパ節転移の有無を問わず，手術標本 より肉眼的に転移の認められないと思われるリンパ節 を採取，2 分割し，一方よりりンパ球を分離し，他方 は病理組織学的検査に用い, 転移の認められないるの を対象とした，良性疾患については手術時，胃大網動 脈に沿らリンパ節（大弯リンパ節）を採取し、リンパ 球を分離した。

2. リンパ球混合培養 (MLC)に和ける killer 練胞産 生能

Raji 細胞 (Burkit lymphoma 由来の B-lymphoblastoid cell line)を Mitomycin処理したるのを stimulator cell とし，リンパ球と6 日間混合培着後, 細胞を採取し，その cytotoxicityを Raji 細胞を標的 細胞として， ${ }^{51} \mathrm{Cr}$ release assay にて測定した。

3. NK 活性の測定

ヒト赤白血病由来の株化細胞である K562を標的細 胞として ${ }^{51} \mathrm{Cr}$ release assay

4. 各種の activated killer 活性の測定 anomalous killer cell (以下 AK) 活性は, 10名以 上の健常人より採取したリンパ球を混合し Mitomycin 処理したすのを stimulator cell とし，6 日 間混合培養することにより誘導した。一方, PHA activated killer cell (以下 PAK) 活性は PHA を1 $\mu \mathrm{g} /$ 
$\mathrm{ml}$ 添加し，また, Lymphokine activated killer cell （以下 LAK）活性は, Lectin free の IL-2を 10 単位 $/ \mathrm{ml}$ 添加し、いずれる 3 日間培養することにより誘導した。 そして細胞を採取し，Raji 細胞を標的細胞として，そ の cytotoxicity を測定した。

5.リンパ球 subset の測定

モノクロナル抗体として OKT3, OKT4, OKT8 (Ortho）および Leu-7 (Beckton Dickinson)を用い て, 間接蛍光抗体法によりリンパ球 subset を測定し た.

\section{成 績}

1. MLC における killer 細胞産生能

(1) PBL とRINC の比較

良性疾患に括いては RLNCはPBL と同程度の活 性を示したが, 胃癌に扔いては RLNC の活性は同一患 者 PBL 括よび良性疾患 RLNCに比べ明らかに低下 しているのが認められた（図 1).

（2） PBL の killer 細胞産生能に及ぼす RLNC 添加 の影響

RLNCを同一患者 PBL に添加し, Raji 細胞と混合 培着することにより誘導される killer 活性を, PBLの み Raji 細胞と混合培養した際に誘導される killer 活 性を比較した。 その結果, PBL の killer 細胞産生能は RLNC 添加によっても抑制されなかった. すなわち, 胃癌所属リンパ節に, PBLの killer 細胞産生能に対す る suppressor 活性は㭘出されなかった。

\section{IL-2産生能}

良性疾患に打いてはRLNCはPBLに比べ有意に 高いIL-2産生能を示したが，胃癌においてもリンパ節 転移の有無を問わず RLNC は PBLに比べ，明らかに 高いIL-2産生能を示した（図 2）.

図 1 リンパ球混合培養における killer 細胞産生能
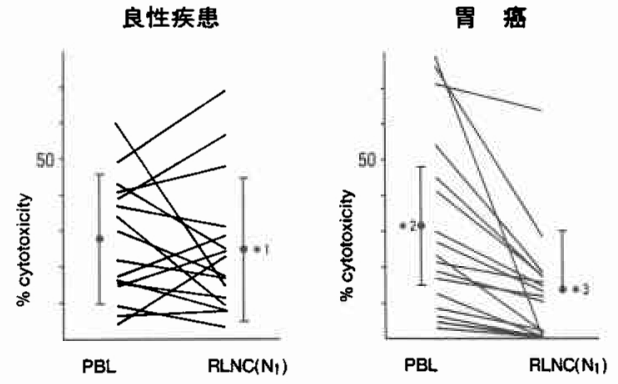

${ }^{*} 2:{ }^{*} 3: \mathrm{p}<0.01$ (paired $\mathrm{t}$ test), ${ }^{*} 1:{ }^{*} 3: \mathrm{p}<0.05$ (Student's $\mathrm{t}$ test)
図 2 IL-2産生能

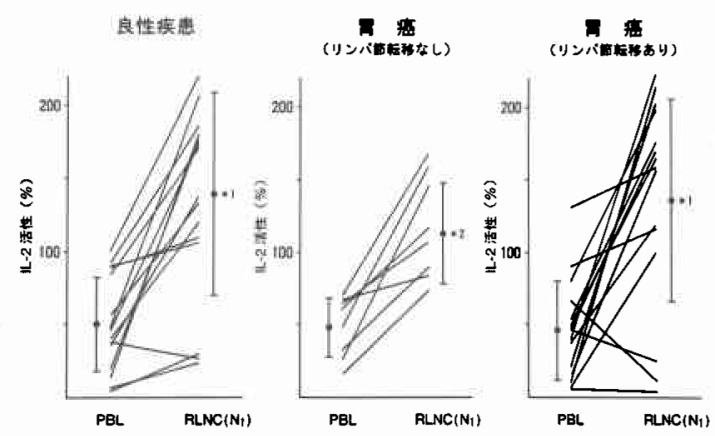

${ }^{*} 1 \mathrm{p}<0.001$ (paired $\mathrm{t}$ test), ${ }^{*} \mathrm{p}<0.01$ (paired $\mathrm{t}$ test)

3. リンパ球の $\mathrm{T}$ cell subset

まず, OKT 3陽性細胞比率については，良性疾患， 胃癌のいずれにおいても PBL とRLNC（第 1 群）と の間に有意差を認めなかった。そこで OKT4/OKT8比 について検討すると，良性疾患に抢いてはPBL と RLNC との間に有意差を認めないものの，胃癌におい てはRLNCはPBLに比べ有意に高値を示すのが認 められた。すなわち, 胃癌 RLNCに扎いてはOKT4陽 性細胞 (helper/indecer T cell) が相対的に增加し, 逆に OKT8陽性細胞 (suppressor/cytotoxic T cell) が減少しているすのと考学られた（表 1).

4. NK 活性

(1) PBL と RLNC の比較

まず PBLの NK 活性についてみると, 良性疾患, 胃 癌でリンパ節転移を認めない例およびリンパ節転移を 有する胃癌患者間に有意差を認めなかった。 そこで RLNC と同一患者 PBL とを比較した（図 3)．その結 果, 良性疾患においては RLNCはPBLに比べ有意に 低い活性を示したが，胃癌においてもリンパ節転移の 有無を問わず, RLNCの NK 活性は明らかに低いのが

表 1 リンパ球の $\mathrm{T}$ cell subset

\begin{tabular}{|c|c|c|c|c|}
\hline & \multicolumn{2}{|c|}{ 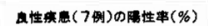 } & \multicolumn{2}{|c|}{ 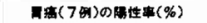 } \\
\hline & PBL & RLNG(N, & PEL. & RLNG(N, \\
\hline окт 3 & $60.3 \pm 17.6$ & $50.1 \pm 16.5$ & $63.5 \pm 7.9$ & $58.9 \pm 7.6$ \\
\hline ОКт 4 & $37.1 \pm 15.9$ & $31.0 \pm 16.7$ & $36.1 \pm 8.6$ & $39.7 \pm 12.5$ \\
\hline ОКт8 & $31.5 \pm 14.3$ & $24.0 \pm 9.2$ & $30.1 \pm 12.8$ & $16.4 \pm 4.8$ \\
\hline$\frac{\text { OKT } 4}{\text { OKT }}$ & $1.3 \pm 0.5$ & $1.4 \pm 0.8$ & $1.4 \pm 0.7$ & $2.6 \pm 1.2$ \\
\hline
\end{tabular}

*1 Mean \pm S.D., * $3:{ }^{*} 4: \mathrm{p}<0.05$ (paired $t$ test), ${ }^{*}: * 4: \mathrm{p}<0.05$ (Student's t test) 
困 3 NK 活性
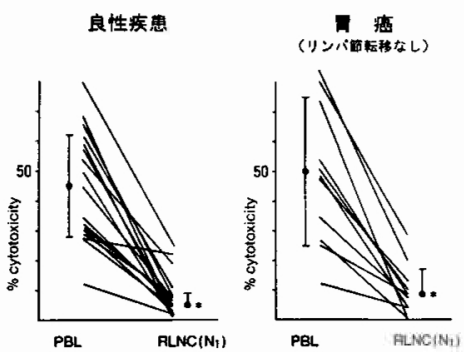

${ }^{*} \mathrm{p}<0.001$ (paired $\mathrm{t}$ test)

認められた。

（2）Leu-7陽性細胞比率

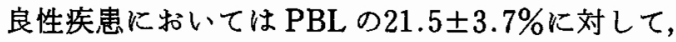

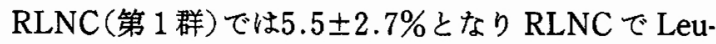
7陽性細胞比率が有意に低いのが認められたが, 胃癌に

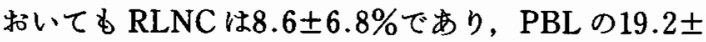
$5.8 \%$ に対して有意に低い比率を示した。

（3） PBLの NK 活性に及ぼす RLNC 添加の影響 PBL，NK 活性は RLNC（第 1 群）添加によって， 良性疾患，胃癌のいずれに扣いてる有意に抑制される のが認められた。これは胃周囲リンパ節に末梢血の NK 活性に対する suppressor 活性が存在する可能性 を示唆する所見と考えられた，なお，この際，suppressor 活性を示す分画はnon-adherent cellで，かつ OKT3陽性細胞すなわちT細胞であると考えられた。

5. activated killer 活性

$\mathrm{AK}$ 活性については胃癌患者についてのみ測定した が, RLNC (第 1 群) は全例 PBL に比べ低い活性を示 した.

次に LAK 活性を検討した（図 4)，その結果，良性 疾患，胃癌のいずれに括いても RLNC（第 1 群）は PBL に比し低い活性を示すのが認められた.

また，PAK活性についても LAK 活性と同様に, RLNC（第 1 群）の活性は良性疾患, 胃癌のいずれに おいても，PBL に比べ低いのが認められた（図 5 ).

\section{考㳟および総括}

腫場に対する免疫監視機構において, 腫瘍関連抗原 に対する killer T 細胞の活性が最も重要な役割をは たしていると考えられてきた。 しかし，実際問題とし ては，癌患者に扣いてこれを測定することは方法論的 に困難な点が多い，そこで，私どすはリンパ球混合培 養 (MLC) におけるアロ抗原に対する killer T 細胞産 生の実験系 ${ }^{1)}$ を用い, RLNC の killer T 細胞産生の基
図 4 LAK 活性
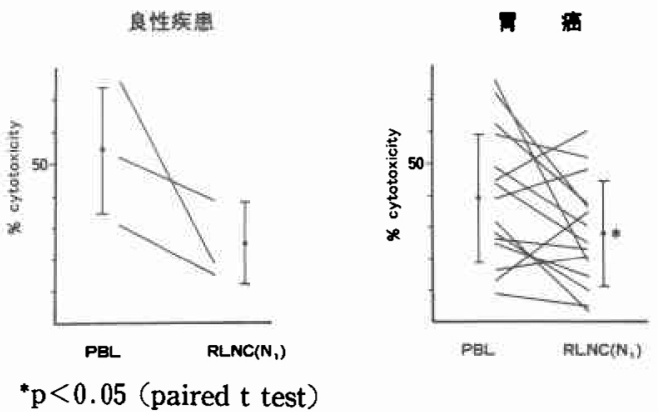

図 5 PAK 活性

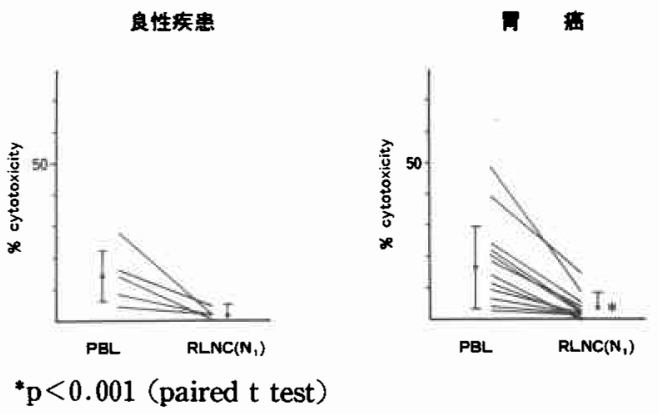

礎的能力の測定を試みた。その結果，良珄疾患におい ては RLNCは PBL と同程度の killer T 細胞産生能 を示したが，胃癌においては明らかに低下しているの が認められた。この胃癌 RLNCに拈ける killer T 細 胞産生能低下の機序については, PBL の killer 細胞産 生に対する RLNC 添加の影響が認められないので suppressor cell の存在によるむのとは考皇にくい. た, killer T 細胞の誘尊・分化に重要な役割をはたし ている2)と考党られる IL-2産生能が, 胃癌 RLNC にお いて低下しているのが羿められないことから IL-2の 関与も否定的である. 一方, $\mathrm{T}$ cell subset の検索で, 胃癌 RLNCに和ける OKT4/OKT8比の上昇が認めら れこれが killer T 細胞産生能の低下と関連づけられ る可能性が示唆された。

癌患者 RLNCの NK 活性については，乳癌3)や大腸 癌)について検討されているが，いずれる PBL に比べ 低いことが報告されている。また，良性疾患に拈いて も低いとの報告がみられる5). 胃周囲 RLNCに関する 私どすの検討でもこれらの報告と一致しており，腫瘍 の存在とは無関係に低いNK 活性を示した。このよう に RLNCの NK 活性が低い機序としては, NK 細胞 に対するモノクローナル抗体と考えられる Leu-7陽性 
細胞比率が低く, NK 担当細胞そのものが量的に少な いこと,さらに suppressor 細胞が存在するという質的 問題す関与しているのではないかと考えられた。

一方, 最近, 種々の刺激にもとづいて活性化してく る非特異的な killer 細胞の存在が注目されている. $\mathrm{LAK}^{6)}, \mathrm{PAK}^{7)}, \mathrm{AK}^{8}$ などと呼ばれる細胞がそれであり 腫湯に対する免疫監視機構に括ける役割が検討されて いる. Grimm ら゙)は, どのリンパ組織にも LAK の前駆 細胞は存在すると報告しているが，私どもの成績では LAK 産生能は，良性疾患，胃癌のいずれにおいても RLNCはPBLに比して有意に低いのが認められた。 また, PAK, AK についても LAK と同様に RLNC に 颃いては低い活性しか示さなかった。

以上，所属リンバ節の killer 活性を測定し末梢血と 比較した。その結果, RLNC は killer T 細胞を産生す る能力を本来 PBL と同程度に有しているすのと思わ れたが，担癌状態に打いては明らかにその機能が低下 していた. また，NK 活性や activated killer 活性など の非特異的な killer 活性も明らかに低いのが認められ た。

このような結果が胃癌患者の抗腫瘍免度における所 属リンパ節の in vivoでの役割を直接反映していると は言いえないが，少なくとも所属りンパ節が積極的に 抗腫韵性に働く結果は得られなかった。すなわち，癌 手術に和いて積極的に所属リンパ節を温存する意義は 認めなかった。

\section{文献}

1) Ware CF, Grager GA: Mechanism of lymphocyte-mediated cytotoxicity I. The effect of anti-human lymphotoxin antisera on the cytolysis of allogeneic B cell lines by MLC sensitized human lymphocytes in vitro. J Immunol 126, 1926, 1981.

2) Kern DE, Gillis $S$, Okada $M$ et al: The role of interleukin-2 (IL-2) in the differentiation of cytotoxic $T$ cells: The effect of monoclonal
anti-IL-2 antibody and absorption with IL-2 dependent $\mathrm{T}$ cell lines. J. Immunol $127: 1323$, 1928

3) Cunningham-Rundles S, Fillipa DA, Braun DW et al: Natural cytotoxicity of peripheral blood lymphocytes and regional lymph node cells in breast cancer in women. JNCI 67 : $585-590,1981$

4) Moore M, Vose BM: Extravascular natural cytotoxicity in man : Anti-K562 activity of lymph-node and tumor-infiltreating lymphocytes. Int J Cancer $27: 265-272,1981$

5) Antonelli P, Stewart W, Dupont B : Distribution of natural killer cell activity in peripheral blood, cord blood, thymus, lymph nodes and spleen and the effect of in vitro treatment with interferon preparation. Clin Immunol Im. munopathol 19:161-169, 1981

6) Grimm EA, Mazumder A, Zhang $\mathrm{HZ}$ et al: Lymphokine-activated killer cell phenomenon. Lysis of natural killer-resistent fresh solid tumor cells by interleukin 2-activated autologous human peripheral blood lymphocytes. J Exp Med 155 : 1823-1829, 1982

7) Mazuumder A, Grimm EA, Rosenberg SA: Characterization of the lysis of fresh human solid tumors by autologous lymphocytes activated in vitro with phytohemagglutinin. J Immunol 130 : 958-963, 1983

8) Seeley JK, Golub AH : Studies on cytotoxicity generated in human mixed lymphocyte cultures. I. Time course and target spectrum of several distinct concomitant cytotoxic activities. J Immunol 120 : 1422, 1978

9) Grimm EA, Ramsey KM, Mazumder A et al : Lymphokine-activated killer cell phenomenon. II. Precursor phenotype is serologically distinct from peripheral $T$ lymphocytes, memory cytotoxic thymus-derived lymphocytes, and natural killer cells. J Exp Med 157 : 884-897, 1983 